\title{
Mitral valve prolapse in hyperthyroidism of two different origins
}

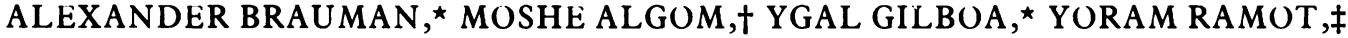 \\ AHUVA GOLIK, ^ DOV STRYJER† \\ From the Departments of ${ }^{\star}$ Internal Medicine B, †Cardiology, and $\ddagger$ Endocrinology, Assaf Harofeh Hospital, Zerifin, \\ Israel
}

SUMMARY The prevalence of mitral valve prolapse was investigated in 126 patients with hyperthyroidism due to Graves' disease or toxic nodular goitre and that of hyperthyroidism in 64 patients with mitral valve prolapse. One hundred and eleven asymptomatic healthy subjects comprised a control group. The patients with hyperthyroidism were divided into those with Graves' disease and those with toxic nodular goitre. Of the group as whole, $12(9.5 \%)$ patients had mitral valve prolapse compared with six $(5.4 \%)$ in the control group, but the difference was not statistically significant. The prevalence of mitral valve prolapse in the patients with toxic goitre was also not significantly different from that in the controls. When the prevalence in the group with Graves' disease was compared with that in the control group (16.3\% vs $5.4 \%)$ the difference was significant. Only one patient with mitral valve prolapse had hyperthyroidism.

Since the first description by Barlow in 1963 of mitral valve prolapse, numerous reports have been published. 12 The prevalence of the condition appears to be increasing partly owing to increased clinical awareness and partly to the increased use of echocardiography, and figures between $1 \%$ and $21 \%$ have been reported in otherwise normal populations. ${ }^{3-6}$ Medical opinion of the clinical importance of mitral valve prolapse also varies. It ranges from being considered to have a poor prognosis owing to a high rate of arrhythmias and endocarditis ${ }^{78}$ to being considered as a normal anatomical variation of the mitral valve apparatus. ${ }^{9}$ Mitral valve prolapse has been reported associated with disorders such as Marfan's syndrome, ${ }^{10}$ osteogenesis imperfecta, ${ }^{11}$ and others. ${ }^{12} 13$

The prognosis is influenced by the causation of the mitral valve prolapse. Primary prolapse generally has a good prognosis while secondary prolapse, especially when due to occlusive coronary disease, is more serious. ${ }^{14}$ Channick et al reported a very high incidence of mitral valve prolapse in patients with hyperthyroidism, ${ }^{15}$ which is possibly related to increased adrenergic tone in both conditions. Our experience of

Requests for reprints to Professor Y Gilboa, Departments of Internal Medicine "B" and Endocrinology, Assaf Harofeh Hospital, Zerifin 70300, Israel.

Accepted for publication 20 November 1984 large numbers of hyperthyroid patients did not indicate such a high prevalence. We therefore decided to investigate a large population drawn from our endocrine and cardiological institutes in order to determine the prevalence of hyperthyroidism in patients with mitral valve prolapse.

\section{Patients and methods}

Three groups of subjects were examined.

Group 1 consisted of 126 hyperthyroid patients, of whom $99(78.6 \%)$ were women (age range 19-76 (mean 44.8$)$ years) and $27(21.4 \%)$ men (age range 28-78 (mean 49.6) years). Most of the patients were euthyroid at the time of examination as a result of various treatments, and only a few were still hyperthyroid. In this group 49 patients had Graves' disease based on a thyroid scan and the accepted clinical criteria of diffuse goitre and exophthalmos. Seventy seven patients had toxic nodular goitre. Patients with chronic or subacute thyroiditis were excluded.

Group 2 consisted of 111 asymptomatic subjects drawn from our inpatient and outpatient population, of whom 88 were women (age range 15-88 (mean 46) years) and 23 men (age range 16-75 (mean 50) years). The proportions of men and women in this group were similar to those in group 1, and none had any endocrine or cardiac abnormalities. This group con- 
Table 1 Frequency of mitral valve prolapse in 126 patients with Graves' disease or toxic nodular goitre (group 1 ) and in controls (group 2)

\begin{tabular}{|c|c|c|c|c|c|c|}
\hline & \multirow{2}{*}{$\begin{array}{l}\text { No (\%) of } \\
\text { patients }\end{array}$} & \multicolumn{2}{|l|}{ Women } & \multicolumn{2}{|l|}{ Men } & \multirow{2}{*}{$\begin{array}{l}\text { Total No (\%) } \\
\text { with MVP }\end{array}$} \\
\hline & & No (\%) & $\begin{array}{l}\text { Mean } \\
\text { age }(y r)\end{array}$ & No (\%) & $\begin{array}{l}\text { Mean } \\
\text { age }(y r)\end{array}$ & \\
\hline $\begin{array}{l}\text { Group 1 } \\
\text { With Graves' disease } \\
\text { With toxic nodular goitre } \\
\text { Group } 2\end{array}$ & $\begin{array}{c}49(38.9) \\
77(61 \cdot 1) \\
111(100)\end{array}$ & $\begin{array}{l}39(79.6) \\
61(79.2) \\
88(97.3)\end{array}$ & $\begin{array}{l}51.9 \\
53.3 \\
44.5\end{array}$ & $\begin{array}{l}10(20.4) \\
16(20.8) \\
23(20.7)\end{array}$ & $\begin{array}{l}44.4 \\
51.6 \\
59.3\end{array}$ & $\begin{array}{l}8(16 \cdot 3) \\
4(5 \cdot 2) \\
6(5 \cdot 4)\end{array}$ \\
\hline
\end{tabular}

MVP, mitral valve prolapse.

stituted the control group, and in order to preclude any bias they were not examined for heart murmurs.

Group 3 consisted of 64 patients, of whom 32 were women (age range 18-62 (mean 28.5) years) and 32 men (age range 15-69 (mean 31.2) years) with both auscultatory and echocardiographic evidence of mitral valve prolapse.

All the subjects in the three groups underwent thyroid function tests (total thyroxine (TT4) by radioimmunoassay, $\mathrm{T} 3$ resin uptake, free thyroxine index and both $M$ mode and cross sectional echocardiography, which were performed on a Smith Kline Echoline 20A echocardiograph with recordings made on a VR12 instrument in both the parasternal long axis and apical four chamber views. The echocardiograms were read by two experienced echocardiographers without prior knowledge of the diagnosis. The criteria for the diagnosis of mitral valve prolapse were mid systolic buckling or pansystolic hammocking $>3 \mathrm{~mm}$ below the $C-D$ line on the $M$ mode echocardiogram and protrusion of the mitral leaflets beyond the plane of the atrioventricular ring in the long axis view and prolapse of the leaflets beyond the mitral annulus in the four chamber view on the cross sectional echocardiogram.

Statistical analysis was performed with the $\chi^{2}$ test.

\section{Results}

Table 1 summarises the sex distribution of patients in groups 1 and 2. Group 1 was subdivided into those with Graves' disease (49 (38.9\%) patients) and those with toxic nodular goitre $(77(61 \cdot 1 \%)$ patients). The proportions of men and women were similar in the two subgroups. In the patients with Graves' disease
$16.3 \%$ had mitral valve prolapse compared with only $5.2 \%$ of those with toxic nodular goitre. In group 2 (the control group), of 111 patients only six (5.4\%) had mitral valve prolapse. Of 64 patients already known to have mitral valve prolapse (group 3) only one was biochemically hyperthyroid but with no clinical manifestations. In both groups 1 and 2 the prevalence of mitral valve prolapse was much higher in women $(10 / 12(83.4 \%)$ and $6 / 6(100 \%)$ respectivel $)$.

Of the 12 hyperthyroid patients with mitral valve prolapse only one had a mid systolic click and a late systolic murmur. Four patients had a faint short systolic murmur which was considered to be functional, and five had neither a click nor a murmur. Some of the other patients in group 1 without prolapse had minor murmurs but no clicks.

Table 2 shows the thyroid function in group 1 at the time of examination; there was no difference in the occurrence of mitral valve prolapse in hyperthyroid or euthyroid patients $(10.3 \%$ and $9.3 \%$ respectively). The frequency of mitral valve prolapse in patients with Graves' disease was significantly higher than in the controls $\left(\chi^{2}=4 \cdot 11, p<0.05\right)$. When the patients with Graves' disease were compared with those with toxic nodular goitre the difference was not significant $\left(\chi^{2}=3.09,0.1>p>0.05\right)$. Similarly the difference was not significant between the toxic nodular goitre group and the controls or between the hyperthyroid group as a whole and the controls.

\section{Discussion}

Channick et al surprisingly found a very high incidence of mitral valve prolapse in patients with hyperthyroidism due to Graves' disease $(41 \%$ of 39

Table 2 Thyroid function of 126 patients with hyperthyroidism (group 1)

\begin{tabular}{lllll}
\hline Thyroid state & $\begin{array}{l}\text { No(\%) of } \\
\text { patients }\end{array}$ & $\begin{array}{l}\text { No (\%) of } \\
\text { women }\end{array}$ & $\begin{array}{l}\text { No(\%) of } \\
\text { men }\end{array}$ & $\begin{array}{l}\text { Total No(\%) } \\
\text { with MVP }\end{array}$ \\
\hline $\begin{array}{l}\text { Hyperthyroid } \\
\text { Euthyroid }\end{array}$ & $30(24 \cdot 6)$ & $25(86 \cdot 2)$ & $5(17 \cdot 2)$ & $3(10 \cdot 3)$ \\
\hline
\end{tabular}

MVP, mitral valve prolapse. 
patients). ${ }^{15}$ One patient with toxic nodular goitre in this series also had mitral valve prolapse. ${ }^{15}$ Until this report, the connection between Graves' disease and mitral valve prolapse was unknown.

Graves' disease and mitral valve prolapse have some similarities, which could point to a common denominator. Graves' disease is seven times more common among women. The ratio of women to men with mitral valve prolapse in reported series varies from $1.4: 1$ in one study ${ }^{16}$ to $3: 1$ in another. ${ }^{17}$ In our series $79.6 \%$ of the patients with Graves' disease were women, and mitral valve prolapse was found in a ratio of $4: 1$ in favour of women (Table 1).

Genetic factors have been identified in Graves' disease ${ }^{18}$ and also in mitral valve prolapse. An incidence of mitral valve prolapse of $50 \%$ in monozygotic twins has been reported. ${ }^{1920}$ The condition was also found in identical twins. ${ }^{21}$ The peak incidence of Graves' disease occurs during the third and fourth decades. Although seen in infancy, ${ }^{22}$ mitral valve prolapse becomes more evident in adult life, possibly owing to progressive myxomatous degeneration of the mitral valve apparatus as a consequence of ischaemic heart disease, connective tissue abnormalities, or trauma. ${ }^{1}$

Graves' disease is known to be associated with the major histocompatibility antigens $\mathrm{Bw} 35, \mathrm{DRw} 3$, and B8. ${ }^{23}$ In patients with mitral valve prolapse some studies showed a higher prevalence of HLA-Bw35 ( $73 \%$ vs $39 \%$ in controls), but only in American black subjects. ${ }^{24}$ Another study of predominantly white patients showed that the A3; Bw35 phenotype is quite specific for mitral valve prolapse. ${ }^{25}$ Nevertheless, in another study no HLA correlation was found in white subjects. ${ }^{26}$ No ABO blood group specifity was found in American black subjects. ${ }^{24}$ Autoimmunity is a well known causative factor in Graves' disease, ${ }^{27}$ and recently it has been mentioned also in the aetiology of mitral valve prolapse. Miklozek et al and Schlant et al reported that 20 out of a total 40 patients with mitral valve prolapse had a positive antinuclear factor compared with only $4 \%$ in a matched control group. ${ }^{28} 29$ Several manifestations usually seen in autoimmune connective tissue disorders (joint pains, rheumatic fever, hair loss, Raynaud's phenomenon, and pleuritis) were found in these patients.

For many years the cardiac manifestations of hyperthyroidism were thought to be mediated by catecholamines or hyperthyroidism to be associated with an increased adrenergic tone. ${ }^{30}$ Aoki et al suggested that the cardiac effects of hyperthyroidism were due to the direct effect of thyroid hormones ${ }^{31}$ rather than induced by catecholamine hypersensitivity. On the other hand, Boudoulas et al found increased catecholamine concentrations and higher adrenergic tone in patients with mitral valve prolapse. ${ }^{32}$ In the present study the incidence of hyper- thyroidism was negligible in a large group of patients with mitral valve prolapse, as found also by others. ${ }^{33}$ Whatever the relation between these two disorders, therefore, it is probably not due to increased adrenergic tone.

In our study we confirmed the findings of Channick et al $^{15}$ of a higher prevalence of mitral valve prolapse in patients with Graves' disease. Although the number of patients that we examined was larger, the proportion of patients with mitral valve prolapse was smaller but still significantly larger than that in euthyroid controls. Moreover, mitral valve prolapse was no more frequent in patients with toxic nodular goitre than in the controls.

\section{References}

1 Jeresaty RM. Mitral valve prolapse. New York: Raven Press, 1979.

2 Wooly CF. The mitral-valve prolapse syndrome. Hosp Pract 1983; 18: 163-74.

3 Brown OR, Kloster FE, De Mots $\mathrm{H}$. Incidence of mitral valve prolapse in the asymptomatic normal [Abstract]. Circulation 1975; 52 (suppl II): 77.

4 Markiewicz W, Stoner J, London E, Hunt SA, Popp RL. Mitral valve prolapse on one hundred presumably healthy young females. Circulation 1976; 53: 464-73.

5 Procacci PM, Savran SV, Schreiter SL, Bryson AL. Prevalence of clinical mitral-valve prolapse in 1169 young women. $N$ Engl f Med 1976; 294: 1086-8.

6 Barlow JB, Pocock WA. The problem of nonejection systolic clicks and associated mitral systolic murmurs; emphasis on the billowing mitral leaflet syndrome. Am Heart f 1975; 90: 636-55.

7 Nolan CM, Kane JJ, Grunow WA. Infective endocarditis and mitral prolapse: a comparison with other types of endocarditis. Arch Intern Med 1981; 141: 447-50.

8 Shappell SD, Marshall CE, Brown RE, Bruce TA. Sudden death and the familial occurrence of mid systolic click, late systolic murmur syndrome. Circulation 1973; 48: 1128-34.

9 Becker AE, DeWit APM. Mitral valve apparatus; a spectrum of normality relevant to mitral valve prolapse. $\mathrm{Br}$ Heart f 1979; 42: 680-9.

10 Read RC, Thal AP, Wendt VE. Symptomatic valvular myxomatous transformation (the floppy valve syndrome): a possible forme fruste of the Marfan syndrome. Circulation 1965; 32: 897-910.

11 Wood SJ, Thomas J, Braimbridge MV. Mitral valve disease and open heart surgery in osteogenesis imperfecta tarda. Br Heart $\mathcal{F}$ 1973; 35: 103-6.

12 Steinfeld L, Yeh HC, Baron M, Dimich I. The variability of mitral valve prolapse (MVP) in rheumatic heart disease [Abstract]. Circulation 1974; 50 (suppl III): 208.

13 Bertriu A, Wigle ED, Felderhof CH, McLoughlin MJ. Prolapse of the posterior leaflet of the mitral valve associated with secundum atrial septal defect. Am F Cardiol 1975; 35: 363-9. 
14 Barlow JB, Pocock WA, Obel IWP. Mitral valve prolapse: primary, secondary, both or neither? Am Heart $\mathcal{F}$ 1981; 102: 140-3.

15 Channick BJ, Adlin EV, Marks AD, et al. Hyperthyroidism and mitral-valve prolapse. $N$ Engl f Med 1981; 305: 497-500.

16 Malcolm AD, Boughner DR, Kostuk WJ, Ahuja SP. Clinical features and investigative findings in presence of mitral leaflet prolapse. Study of 85 consecutive patients. Br Heart F 1976; 38: 244-56.

17 Cheitlin MD, Byrd RC. The click-murmur syndrome: a clinical problem in diagnosis and treatment. $\mathscr{F A M A}$ 1981; 245: 1357-61.

18 Williams RH. Textbook of endocrinology. 5th ed. Philadelphia: WB Saunders, 1974: 165-6.

19 Schutte JE, Gaffney FA, Blend L, Blomqvist CG. Distinctive anthropometric characteristics of women with mitral valve prolapse. Am $\mathcal{F}$ Med 1981; 71: 533-8.

20 Vercheur OV. Die Zwillingsforschung im Dienste der Inneren Medizin. Verh Dtsch Ges Inn Med 1958; 64: 262-73.

21 Rotmensch $\mathrm{HH}$, Ayzenberg O, Jacobi JJ, Laniado S. Mitral valve prolapse in identical twins [Letter]. Arch Intern Med 1980; 140: 1249.

22 Chandraratna PAN, Vlahovich G, Kong Y, Wilson D. Incidence of mitral valve prolapse in one hundred clinically stable newborn baby girls; an echocardiographic study. Am Heart f 1979; 98: 312-4.

23 Friedman JM, Fialkow PJ. The genetics of Graves' disease. Clin Endocrinol Metab 1978; 7: 47-65.

24 Kachru RB, Telischi M, Cruz JB, Patel R, Towne WD.
HLA and ABO blood group in blacks with mitral-valve prolapse [Letter]. $N$ Engl f Med 1978; 299: 1467.

25 Braun WE, Ronan J, Schacter B, Gardin J, Isner J, Grecek D. HLA antigens in mitral-valve prolapse. Transplant Proc 1977; 9: 1869-71.

26 Jeannet $\mathbf{M}$, Bloch A. HLA types in mitral-valve prolapse [Letter]. N Engl f Med 1979; 301: 108.

27 Kidd A, Okita N, Row VV, Volpe R. The immunologic aspects of Graves' and Hashimoto's diseases. Metabolism 1980; 29: 80-99.

28 Miklozek CL, Schlant RC, Hurst JW. Antinuclear antibodies in the mitral-valve syndrome [Abstract]. Circulation 1978; 58: 235.

29 Schlant RC, Felner JH, Miklozek CL, Lutz JF, Hurst JW. Mitral valve prolapse. DM 1980; 26: 1-51.

30 Grossman W, Robin NI, Johnson LW, Brooks H, Selenkow HA, Dexter L. Effects of beta blockade on the peripheral manifestations of thyrotoxicosis. Ann Intern Med 1971; 74: 875-9.

31 Aoki VS, Wilson WR, Theilen EO. Studies of the reputed augmentation of the cardiovascular effects of catecholamines in patients with spontaneous hyperthyroidism. F Pharmacol Exp Ther 1972; 181: 362-8.

32 Boudoulas H, Reynolds JC, Mazzaferri E, Wooley CF. Metabolic studies in mitral valve prolapse syndrome; a neuroendocrine-cardiovascular process. Circulation 1980; 61: $1200-5$.

33 Buccino RA, Spann JF Jr, Pool PE, Sonnenblick EH, Braunwald $E$. Influence of the thyroid state on the intrinsic contractile properties and energy stores of the myocardium. f Clin Invest 1967; 46: 1669-82. 